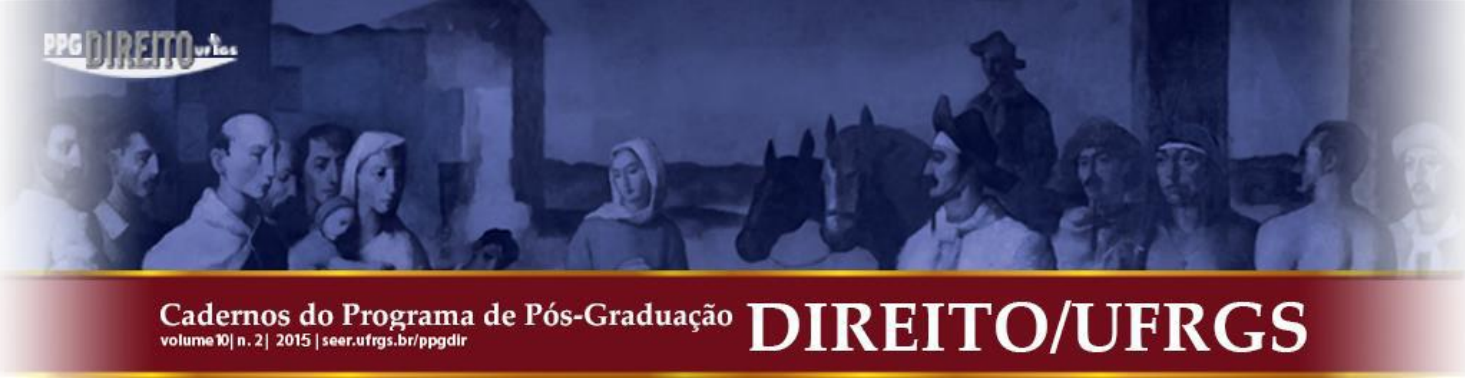

\title{
O DEVER DE DEIXAR SEM EFEITO OS CONTRATOS AFETADOS POR ATOS DE CORRUPÇÃO
}

\author{
THE DUTY TO RENDER INEFFECTIVE THE CONTRACTS AFFECTED BY \\ ACTS OF CORRUPTION
}

Carlos Aymerich Cano*

\begin{abstract}
RESUMO: A obrigação de anular ou resolver os contratos públicos afetados por crimes de corrupção, embora reconhecida no papel, segue a ser uma matéria pendente nos ordenamentos espanhol e europeu. $\mathrm{O}$ presente trabalho analisa as questões que levantam os escassos acórdãos ditados pela jurisdição criminal anulando estes atos e contratos, apontando as potencialidades de figura do confisco.

PALAVRAS-CHAVE: Contratos públicos. Corrupção. Anulação. Confisco.
\end{abstract}

\begin{abstract}
The duty to annul or end public contracts affected by crimes of corruption, although recognized on paper, keeps being a pending issue in Spanish and European legal systems. The present work analyzes the issues that raise the few judgments rendered by the criminal jurisdiction holding these acts and contracts null, pointing out to the potential of the confiscation figure.
\end{abstract}

KEYWORDS: Public Contracts. Corruption. Annulment. Confiscation.

SUMÁRIO: 1 . A obrigação de retirar qualquer efeito dos contratos decorrentes de atos de corrupção. 1.1. Instrumentos internacionais em matéria de luta contra a corrupção. 1.1.1. OCDE. 1.1.2. Conselho de Europa. 1.1.3. Nações Unidas. 1.2. Instrumentos internacionais de harmonização legislativa em matéria de contratação pública. 1.2.1. Acordo de contratação pública da OMC. 1.2.2. Lei Modelo da UNCITRAL. 1.3. Direito comunitário europeu. 2. O cumprimento do dever de retirar efeitos aos contratos afetados por corrupção no ordenamento espanhol. 2.1. A anulação de atos e contratos administrativos pela jurisdição criminal como questão prejudicial administrativa não devolutiva. 2.2. A anulação de atos e contratos administrativos como manifestação da competência civil adesiva do juiz penal. 2.3. Um caso excecional: a jurisdição criminal declara-se incompetente para anular atuações administrativas. 3. Conclusão. A anulação de atos e contratos administrativos como confisco dos produtos do delito. Referências.

\section{A OBRIGAÇÃO DE RETIRAR QUALQUER EFEITO DOS CONTRATOS DECORRENTES DE ATOS DE CORRUPÇÃO}

As novas Diretivas europeias de contratos e concessões públicas de 2014, bem como a prática totalidade dos instrumentos internacionais em matéria de luta contra a corrupção ratificados pelo Estado espanhol impõem - ou, no mínimo, permitem - a anulação ou a rescisão dos contratos celebrados em consequência de um ato de corrupção o em que o contratante se achar incurso num suposto de exclusão decorrente da comissão de um delito de corrupção.

O estabelecimento de este dever de anulação é resultado de um processo lento de evolução de dois grupos de normas diferentes. De um lado, as normas internacionais de prevenção e luta contra a corrupção que, por razões óbvias, dedicam à contratação pública uma atenção preferente. De outro, as normas internacionais de

\footnotetext{
* Professor Titular de Direito Administrativo da Universidade da Coruña, Espanha.
} 


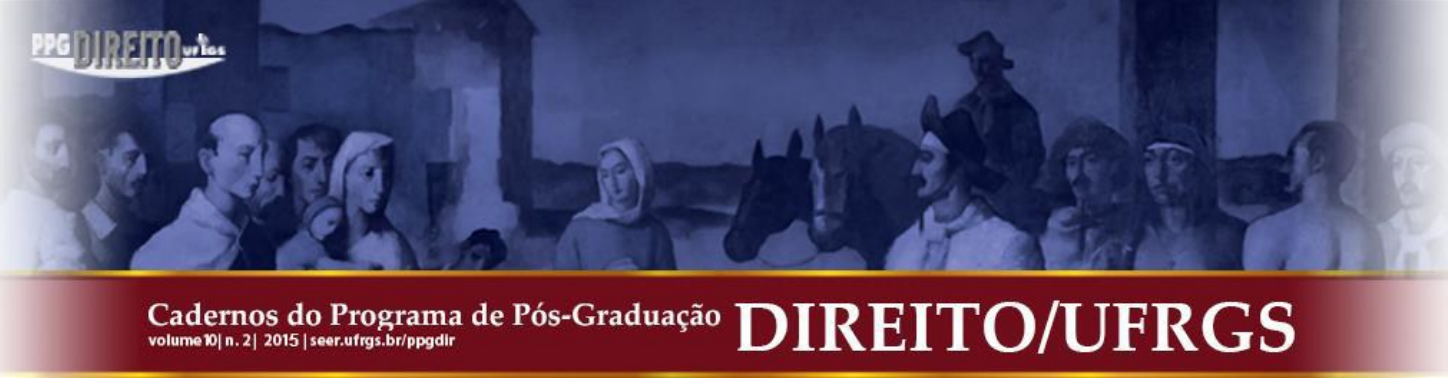

harmonização da atividade contratual pública, de âmbito global ou regional, especialmente preocupadas com a prevenção da corrupção e, sobretudo, com a instauração de mecanismos eficazes de recurso capazes de assegurarem, de forma rápida e efetiva, a observância das normas substantivas.

\subsection{Instrumentos Internacionais em Matéria de Luta Contra a Corrupção}

Tanto a Convenção da OCDE contra a corrupção de funcionários públicos estrangeiros nas transações comerciais internacionais $(1997)^{1}$ quanto a Convenção Civil em matéria de corrupção do Conselho de Europa (1999) ${ }^{2}$ como também a Convenção das Nações Unidas contra a Corrupção $(2004)^{3}$ estabelecem a obrigação de retirar qualquer efeito aos contratos decorrentes de atos de corrupção.

Traços comuns de estes instrumentos são o respeito pela autonomia procedimental e institucional dos Estados signatários ${ }^{4}$ bem como o caráter facultativo, não obrigatório, de grande parte das sanções e mecanismos neles previstos ${ }^{5}$. É por isso que, ante a falta de sanções, a eficácia das suas previsões é confiada, principalmente, à publicidade das avaliações periódicas a que os países que delas fazem parte se submetem.

\footnotetext{
${ }^{1}$ Cfr., art. 3.3 desta Convenção e parágrafos 21 e 22 dos comentários elaborados pela Conferência Negociadora em 21 de Novembro de 1997.

${ }^{2}$ Cfr., art. 8 da Convenção que, sob o expressivo título de "Validez de contratos", dispõe que "cada Parte disporá no seu Direito interno a nulidade de qualquer contrato ou cláusula contratual que tiver por objeto um ato de corrupção".

${ }^{3} \mathrm{O}$ artigo 34 da Convenção, sob o título "Consequências dos atos de corrupção", estabelece que "Com a devida consideração aos direitos adquiridos de boa-fé por terceiros, cada Estado Parte, em conformidade com os princípios fundamentais de sua legislação interna, adotará medidas para eliminar as consequências dos atos de corrupção. Neste contexto, os Estados Partes poderão considerar a corrupção um fator pertinente em procedimentos jurídicos encaminhados a anular ou deixar sem efeito um contrato ou a revogar uma concessão ou outro instrumento semelhante, o adotar qualquer outra medida de correção".

${ }^{4}$ No sentido de que será o ordenamento interno o que regula os procedimentos, as vias de recurso e os órgãos competentes para os tramitar e resolver.

5 O guía para a aplicação legislativa da CNUCC (versão inglesa acessível em http://www.unodc.org/pdf/corruption/CoC_LegislativeGuide.pdf) organiza o conteúdo da CNUCC em mandados obrigatórios - obrigação de adotar medidas medidas legislativas ou de outra natureza -, mandados optativos - em que a obrigação limita-se à sua tomada em consideração - e medidas optativas - definidas como aquelas que os Estados signatários “podem ter vontade de tomar em consideração” (pág. 1).
} 


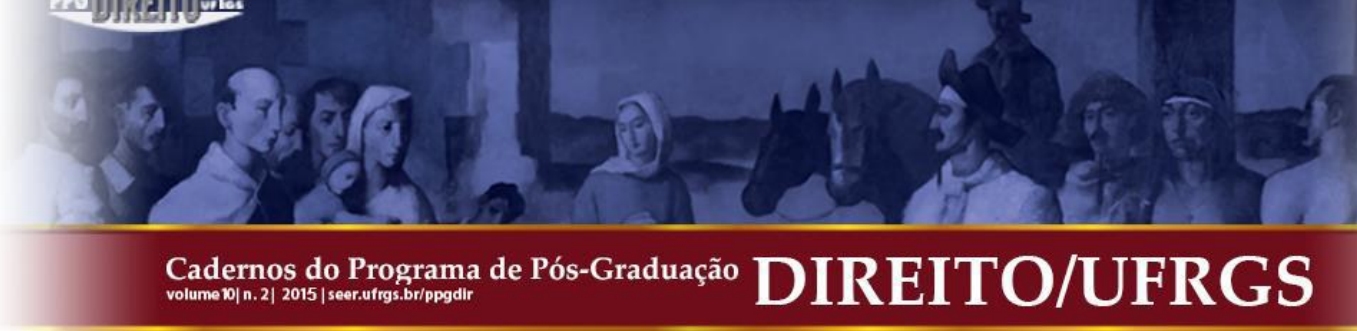

\subsubsection{OCDE}

A referida Convenção da OCDE dispõe no seu art. 3.3 que "cada Parte deverá todas as medidas necessárias a garantir que o suborno e o produto da corrupção de funcionário público estrangeiro, ou o valor dos bens correspondentes a tal produto, sujeitos a retenção e confisco ou que sanções financeiras de efeito equivalente sejam aplicáveis". Estas sanções, de conformidade com a alínea $1^{a}$ do referido preceito, terão "eficazes, proporcionais e dissuassivas". Os comentários da Conferência Negociadora clarificam ainda que por "produto da corrupção" há que entender os "benefícios ou vantagens que o corruptor obtiver da transação ou qualquer outro benefício irregular obtivesse ou conservasse por meio do ato de corrupção”. Pelo seu lado, consoante interpretação autêntica da Convenção, o conceito de confisco englobaria também " $a$ caducidade dos direitos" bem como "a privação permanente da propriedade por um tribunal ou de outra autoridade competente sem prejuízo dos direitos das vítimas"

Pelo seu turno, a "Recomendação para reforçar a luta contra a Corrupção de Agentes Públicos Estrangeiros em Transações Económicas Internacionais” (2009) teima neste dever ao aconselhar no seu ponto XI.i que "as leis e os regulamentos dos países membros devem permitir às autoridades suspenderem —num grau adequadoos concursos para a obtenção de contratos públicos ou vantagens públicas de outro tipo, incluídos os contratos de aquisições públicas e os contratos financiados com ajuda oficial para o desenvolvimento, às empresas decididas a subornar agentes públicos estrangeiros em contravenção das leis nacionais desse país membro e, desde que um país membro aplicar sanções em matéria de aquisições às empresas decididas a subornar agentes públicos nacionais, essas sanciones aplicar-se-ão por igual ao suborno de agentes públicos estrangeiros"7.

Há que reconhecer, porém, que o caráter facultativo da apreensão e do confisco explicam o fato de estas medidas somente se aplicarem, de acordo com um estudo elaborado

\footnotetext{
6 Ambos e dois textos podem ser consultados em http://www.oecd.org/daf/antibribery/ConvCombatBribery_Spanish.pdf.

${ }^{7}$ Ibidem, pág. 21.
} 


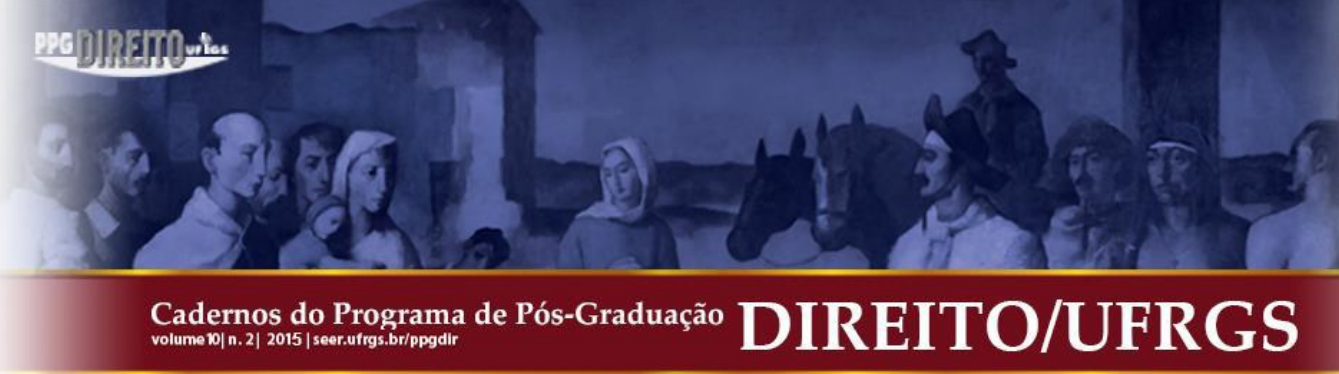

pela própria OCDE publicado em dezembro de $2014^{8}$, num $13 \%$ dos casos analisados. E também que apenas no $41 \%$ desses casos o valor do confisco ultrapassasse o lucro obtido por meio do ato de corrupção 9 . Tal situação decorre, em boa medida, de a maioria das sanções aplicadas pelos órgãos administrativos ou judiciários dos Estados signatários terem sido impostas por meio de acordos ou transações opacas, porquanto raramente o seu conteúdo é feito público ${ }^{10}$. Além do mais, note-se que nalguns Estados como o espanhol não foi concluído nenhum dos processos abertos por corrupção internacional ${ }^{11}$ apesar das duvidosas estratégias comerciais que algumas importantes multinacionais espanholas empregam no exterior $^{12}$.

\subsubsection{Conselho de Europa}

O artigo 8 da Convenção Civil do Conselho de Europa contra a Corrupção ${ }^{13}$, sob o expressivo título de "Validade de contratos", dispõe que "cada Parte disporá em seu Direito interno a nulidade de qualquer contrato ou de qualquer cláusula contratual que tenha por objeto um ato de corrupção". Segundo o Parecer explicativo, na maioria dos ordenamentos europeus não apenas os contratos constitutivos de um ato de corrupção (contratos criminalizados), mas também os que sejam consequência deles são considerados nulos e

\footnotetext{
${ }^{8}$ Cfr., OECD Foreign Bribery Report. An analysis of the Crime of Bribery of Foreign Officials, OECD Publishing, 2014, pág. 18: "Confiscation was applied in only 13\% of cases where information was available, despite the requirement in Article 3(3) of the OECD Anti-Bribery Convention that Parties confiscate the instrument of the bribe and its proceeds or property of equivalent value. This low proportion of confiscation could be explained by the fact that in many cases the company or companies involved paid "disgorgement" or had the proceeds of the foreign bribery confiscated, whereas the individuals in question were either fined or received suspended or actual prison sentences. The highest amount forfeited by an individual in a foreign bribery case to date is USD 149 million". Documento acessível em http://dx.doi.org/10.1787/9789264226616en.

${ }^{9}$ Ibidem., p. 28.

${ }^{10}$ Ibidem, p. 34.

${ }^{11}$ Ibidem, p. 31.

${ }^{12}$ Veja-se, apenas por citar o exemplo mais recente, as suspeitas de suborno que rodeiam a atuação da filial mexicana de OHL, concessionária do Viaducto del Centenario em México DF (vide. http://www.jornada.unam.mx/ultimas/2015/06/01/ohl-mexico-denuncia-campana-en-su-contra-y-ratifica-a-sudirector-6787.html).
}

$13 \mathrm{O}$ texto oficial da Convenção, em inglês e francês, pode consultar-se em https://rm.coe.int/CoERMPublicCommonSearchServices/DisplayDCTMContent?documentId=090000168007f3f 3 . 


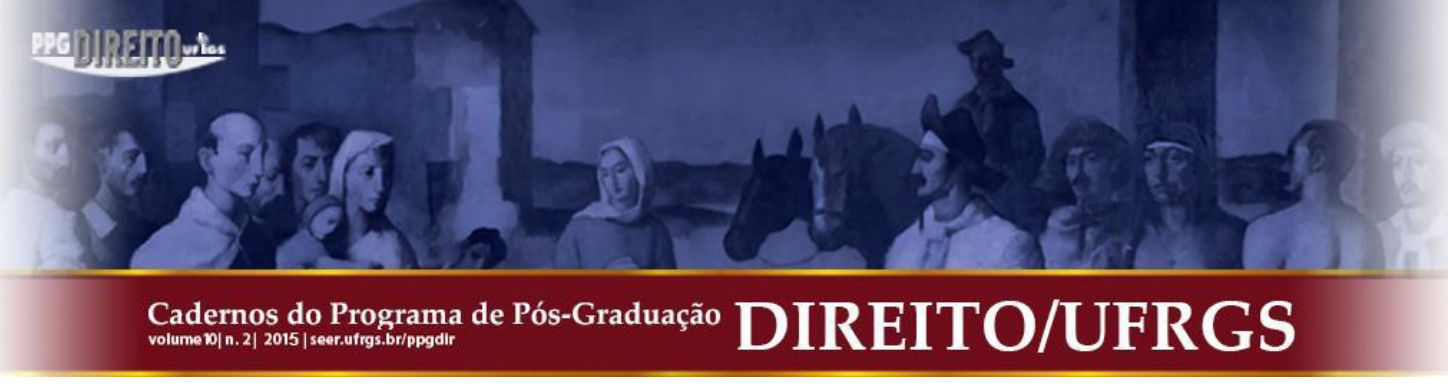

ineficazes ${ }^{14}$. Dada à generalidade do preceito, semelha longe de qualquer dúvida que por contratos há que entender tanto contratos privados quanto contratos públicos.

Todavia, o alcance de esta cláusula resulta limitado pela remissão que a segunda alínea do artigo 8 efetua aos ordenamentos internos, ao lhes permitir optar, se assim o decidirem, por fazer possível que a invalidade de esses contratos afetados por atos de corrupção possa ser instada pelos particulares atingidos. Como o Relatório já referido indica ${ }^{15}$, o que a Convenção faz é prever uma via de recurso adicional para quem resulta prejudicado por um ato de corrupção. Seja como for, a legislação interna dos Estados signatários tem de contemplar necessariamente o direito desses prejudicados a reclamarem uma indemnização pelos danos e prejuízos que se lhes irrogaram.

\subsubsection{Nações Unidas}

O artigo 34 da Convenção das Nações Unidas contra a Corrupção (doravante, CNUCC), sob o título "Consequências dos atos de corrupção", estabelece que "com a devida consideração aos direitos adquiridos de boa-fé por terceiros, cada Estado Parte, em conformidade com os princípios fundamentais de sua legislação interna, adotará medidas para eliminar as consequências dos atos de corrupção. Neste contexto, os Estados Partes poderão considerar a corrupção como um fator pertinente em procedimentos encaminhados a anular o deixar sem efeito um contrato ou a revogar uma concessão ou outro instrumento semelhante ou adotar qualquer outra medida de correção".

Tal e como reconhece o Guia Técnico para a aplicação da CNUCC, elaborada pela Oficina das Nações Unidas contra a Droga e a Delinquência (ONUDD), o único mandado contido no preceito é apenas o adotar medidas para eliminar as consequências dos atos de corrupção ${ }^{16}$. Quais hajam de ser estas, quem as possa instar, por meio de quais procedimentos

\footnotetext{
14 O parágrafo 63 do Relatório explicativo elaborado pelo próprio Conselho de Europa aclara que "Indeed, in most European countries, the contract the cause of which is illegal is null and void". Vide http://conventions.coe.int/Treaty/en/Reports/Html/174.htm.

${ }^{15}$ Ibidem, parágrafo 64.
}

16 documento $\quad$ pode consultar-se $\quad$ em

http://www.unodc.org/documents/corruption/Technical_Guide_UNCAC.pdf. Em concreto, relativamente a este mandado de eliminação das consequências dos atos de corrupção, o referido Guia indica que "Practitioners will be confronted with the consequences of corruption while acting in various functions. More specifically, the practitioners dealing with administrative acts such as concessions, procurement decisions etc., would face the issue in the legal and administrative review of such acts when it turns out that corruption had been involved in a previous decision. Participants in private lawsuits on the consequences of corruption would need to handle the 


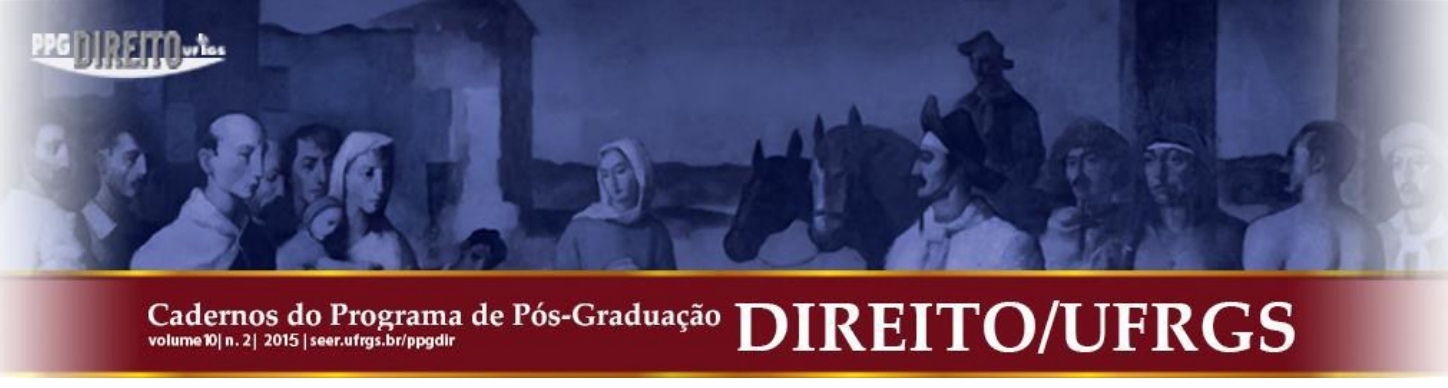

tenham se impor ou quais os órgãos competentes são, todas elas, questões remitidas à discrição dos legisladores estatais. De fato, o Guia para a aplicação legislativa da CNUCC sintetiza o conteúdo normativo de este artigo 34 o limitando à obrigação de os Estados signatários da Convenção "abordar" (address) normativamente as consequências jurídicas dos atos de corrupção acrescentando, com caráter facultativo, que "neste contexto, os Estados podem considerar ainda a possibilidade de anular ou rescindir um contrato, revogar uma concessão ou alguma figura similar ou adotar qualquer medida corretora" ${ }^{17}$.

\subsection{Instrumentos internacionais de harmonização legislativa em matéria de contratação pública}

A diferença dos focados na luta contra a corrupção que, como já foi indicado, obrigam os Estados signatários a anular ou rescindir os contratos que sejam consequência ou instrumento de um ato de corrupção, os acordos e textos internacionais dedicados à contratação pública tais como o Acordo de Contratação Pública da OMC ou a Lei Modelo da Comissão das Nações Unidas para o Direito Comercial Internacional (UNCITRAL pelas suas siglas inglesas) estabelecem expressamente a possibilidade de optar entre "medidas corretivas" - entre elas as de caráter anulatório ou rescisório - ou uma compensação económica adequada. Porém, entanto os instrumentos de luta contra a corrupção não contêm previsão nenhuma de caráter procedimental, tanto o Acordo Revisado da OMC quanto a Lei Modelo da UNCITRAL - e, por influência direta de eles, a maioria de acordos comerciais, bilaterais ou multilaterais, reguladores da contratação pública ${ }^{18}$ - estabelecem os requisitos mínimos que hão de reunir os mecanismos de recurso - legitimação, prazo de tramitação, possibilidade e condições de adoção de medidas cautelares - bem como as que têm de cumprir os organismos encargados de os resolver - assim como as condições de independência e imparcialidade e os poderes com que eles devem contar. Seja como for,

question of (in)validity, (un)enforceability or modification of contracts procured by corruption. In addition, the government officials who design anti-corruption strategies for administration and the judiciary would need to take the problem into account in order to allow the respective institutions to be prepared for the legal proceedings where the consequences of corruption become relevant. The tax officials may need to handle cases of tax deductions where expenditures turn out to be disguised bribes" (p. 110).

${ }^{17}$ Tradução do autor. Cfr., Legislative Guide for the implementation of the United Nations Convention against Corruption, p. 126 e 147 (o documento pode $\begin{array}{llllll}\text { ser } & \text { consultado }\end{array}$ http://www.unodc.org/pdf/corruption/CoC_LegislativeGuide.pdf.

${ }^{18}$ Veja-se o documento preparado pelo Secretariado da OMC no curso dos trabalhos de revisão do Acordo de Contratación Pública de 1994 S/WPGR/W/49, de 31 de agosto de 2004 sobre Disposiciones en materia de contratación pública en los acuerdos de integración económica (acessível em https://www.wto.org/spanish/tratop_s/gproc_s/gpserv_s.htm). 


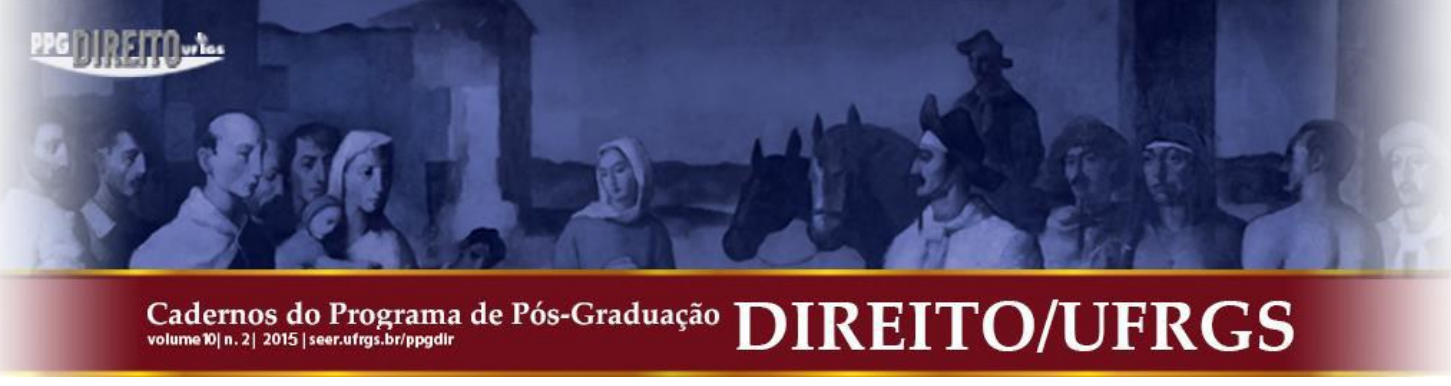

deve-se notar que esta opção supõe um claro avance a respeito de versões antecessoras nas quais, propositadamente, era omitida qualquer referência a essa possibilidade ${ }^{19}$.

\subsubsection{Acordo de Contratação Pública da OMC}

Em 6 de abril de 2014 começou a vigorar a Revisão do Acordo sobre Contratação Pública da OMC, após ter sido ratificado por dois terços dos Estados e Organizações Partes.

O artigo XVIII, alínea 7, do texto revisado do Acordo sobre Contratação Pública da OMC (2012) dispõe que “cada Parte adotará ou manterá procedimentos que prevejam (b) quando o órgão de revisão determinar a existência de uma infração ou descumprimento das referidas no parágrafo 1, medidas corretivas ou uma compensação pelas perdas ou danos e prejuízos sofridos, que poderá limitar-se aos custos da preparação da proposta ou aos custos relacionados com a impugnação ou ambos e dois" ${ }^{20}$.

A principal questão interpretativa que o preceito levanta é a de se os legisladores estatais podem se limitar apenas a escolher uma das medidas alternativas - correção do descumprimento ou indemnização por danos - ou se, pelo contrário, a escolha corresponde ao licitador afetado. Com caráter geral, a doutrina inclina-se mais para a segunda opção. Assim, para ARROWSMITH ${ }^{21}$ o princípio de efeito útil estabelecido na alínea 2 do artigo XX (artigo XVIII.1 do Acordo revisado) impõe esta interpretação por quanto se só contemplasse a

\footnotetext{
${ }^{19} \mathrm{O}$ silêncio justificava-se, para o caso da Lei Modelo da UNCITRAL de 1994 no caráter especialmente perturbador da anulação de um contrato já adjudicado que, além do mais, poderia resultar contrária ao interesse público ("There may be cases in which it would be appropriate for a procurement contract that has entered into force to be annulled. This might be the case, for example, where a contract was awarded to a particular supplier or contractor as a result of fraud. However, as annulment of procurement contracts may be particularly disruptive of the procurement process and might not be in the public interest, it has not been provided for in the Model Law itself. Nevertheless, the lack of provisions on annulment in the Model Law does not preclude the availability of annulment under other bodies of law. Instances in which annulment would be appropriate are likely to be adequately dealt with by the applicable contract, administrative or criminal law", cfr., "Guide for enactment of UNCITRAL model law on procurement of goods, construction and services" (1994), art. 54, par. $12 \mathrm{http}: / / \mathrm{www}$. uncitral.org/pdf/english/texts/procurem/ml-procurement/ml-procure.pdf). De fato, este foi uma das principais questões submetidas ao Grupo de Trabalho que preparou a revisão do texto de 1994 da que resultaria a Lei Modelo atual de 2011 (vide NICHOLAS. Remedies for breaches and UNCITRAL Model Law. Public Procurement Law. Damages as an Effective Remedy. Oxford: Hart, 2011, p. 222).
}

\footnotetext{
${ }^{20}$ Neste ponto o novo texto é quase idêntico ao do Acordo original de 1994, que em seu artigo XX.7.c estabelecia que "os procedimentos de impugnação preverão ... uma retificação da infração do Acordo ou uma compensação pelos danos e prejuízos sofridos, que se poderá limitar às despesas de preparação da proposta ou da reclamação.

${ }^{21}$ Cfr., ARROWSMITH, S. The character and role of national challenge procedures under the Government Procurement Agreement. PPLR, 2002, 4, p. 250. No mesmo sentido XINGLIN ZHANG. Constructing a system of challenge procedures to comply with the Agreement on Government Procedure. In: ARROWSMITH y ANDERSON (Eds.). The WTO Regime on Government Procurement: Challenge and Reform. Cambridge: Cambridge University Press, 2011, p. 495.
} 


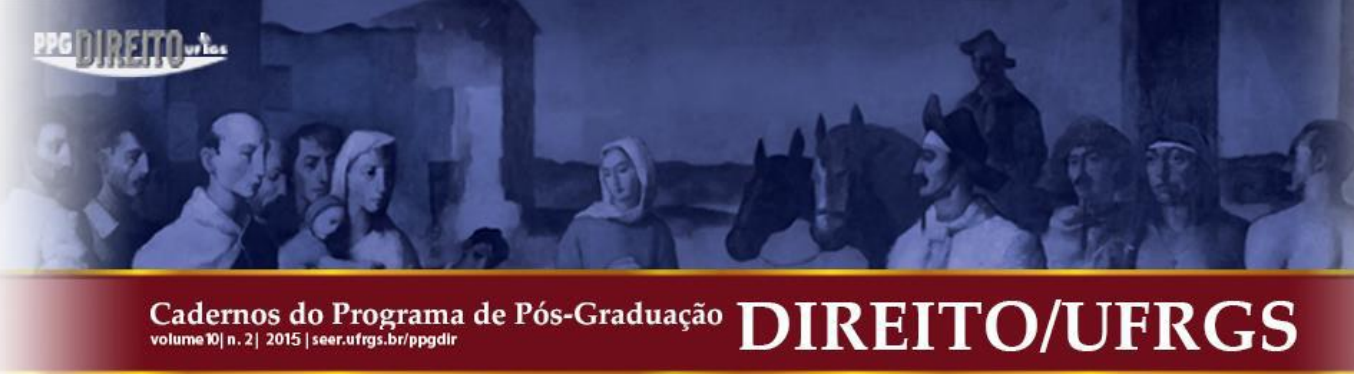

possibilidade de solicitar uma indemnização, esta via resultaria impraticável no caso de procedimentos de adjudicação sem licitação nos quais, via de regra, não há despesas de preparação de proposta.

No que diz respeito ao significado da expressão "medidas corretivas", tende a se aceitar que dentro de ela tem cabimento a anulação de contratos já adjudicados ao não conter o texto do Acordo previsão nenhuma que impeça essa possibilidade ${ }^{22}$. Seja como for, ARROWSMITH adverte que a adoção de essas medidas corretivas pode denegar-se se da demora ou paralização do contrato delas resultante decorressem prejuízos graves para o interesse público ${ }^{23}$.

\subsubsection{Lei Modelo da UNCITRAL}

O artigo 67.9 da Lei Modelo da UNCITRAL sobre Contratação Pública (2011) ${ }^{24}$, dispõe que a decisão adotada pelo órgão estatal independiente resolvendo o recurso de revisão regulado nesse preceito poderá “(c) Revogar, total ou parcialmente, qualquer ato ou decisão da entidade adjudicadora que não se ajustar ao disposto na presente Lei [, exceto que se tratar de um ato ou decisão que valide o contrato adjudicado ou o acordo quadro celebrado]”, “(d) Revisar qualquer decisão da entidade adjudicadora que não se adequar ao disposto presente Lei [, desde que não seja um ato ou decisão pelo que dê vigência ao contrato adjudicado ou ao acordo quadro celebrado]” o "(f) Revogar qualquer adjudicação de contrato ou todo e qualquer acordo quadro a entrada em vigor do qual não se ajustar à presente Lei e, de se ter publicado a adjudicação, ordenar que se publique um aviso da sua revogação".

Se referindo a este preceito, o Guia de aplicação da Lei Modelo ${ }^{25}$ oferece, a respeito de este preceito, alguns comentários de interesse. Em primeiro lugar, que a discricionariedade que a norma reconhece aos legisladores estatais - expressada no texto por meio das alternativas contidas entre parênteses quadrados - relativamente aos meios deve considerar-se limitada, quanto aos fins diz respeito, à garantia de um sistema efetivo de revisão "como o

\footnotetext{
${ }^{22}$ Nesse senstido XINGLIN ZHANG. op. cit., p. 495.

${ }^{23}$ Cfr., ARROWSMITH, S. op. cit., p. 250.

${ }^{24}$ Acessível em http://www.uncitral.org/uncitral/es/uncitral_texts/procurement_infrastructure/2011Model.html.

${ }^{25}$ Pode consultar-se em http://www.ppi-ebrd-uncitral.com/images/pre-guide-2012.pdf.
} 


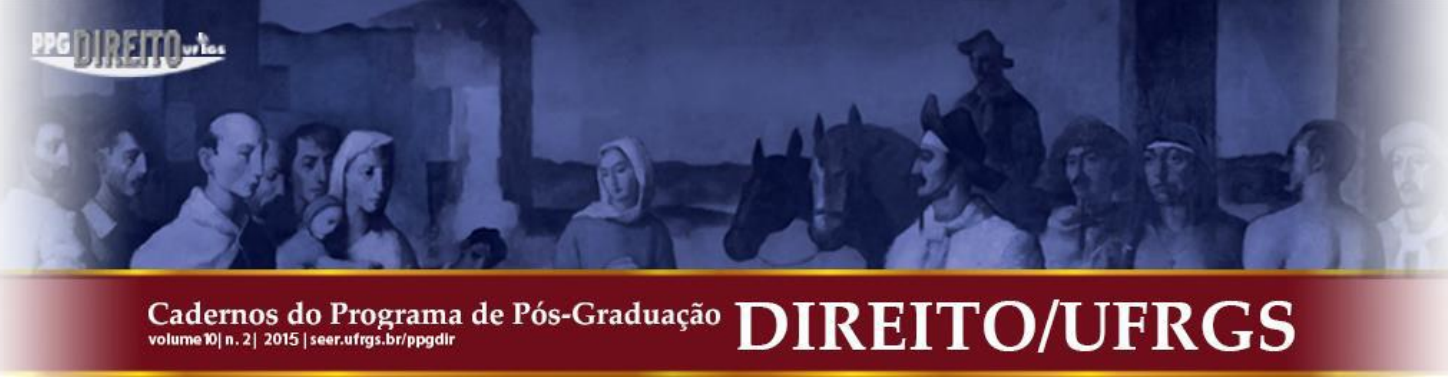

requerido pela CNUCC ${ }^{26}$ ". Assim sendo, em segundo lugar, a Lei Modelo outorga expressamente aos legisladores estatais a opção de alterar ("overturn") ${ }^{27}$, confirmar ou anular os atos ou decisões adotados pela entidade adjudicadora, incluída a própria adjudicação de um contrato ou de um acordo quadro já celebrado e em execução ("that has entered into force") ${ }^{28}$. Por último, ainda respeitando o caráter facultativo de estas disposições, o citado Guia de Aplicação advoga expressamente por outorgar preferência às medidas corretivas sobre a indemnização de danos e prejuízos. Reconhece, em qualquer caso, que a compensação pode constituir uma medida apropriada em determinados supostos, particularmente quando o contrato já tivesse sido adjudicado e não se considerar apropriado, em atenção ao interesse público, interferir nele ${ }^{29}$.

Em conclusão, também a Lei Modelo da UNCITRAL de 2011 enxerga a possibilidade, com o caráter não prescritivo que lhe é próprio, de anular os contratos adjudicados em vulneração das normas substantivas aplicáveis e, notadamente, dos que sejam constitutivos de um ato de corrupção ou consequência dele ${ }^{30}$.

\footnotetext{
${ }^{26}$ Cfr., parágrafo 23 , p. 248 . Lembrando qual é o sistema de revisão requerido pela CNUCC, o próprio guia (parágrafo 3, p., 228) indica que "article $9(1)(d)$ of the United Nations Convention against Corruption requires procurement systems to include an effective challenge mechanism, termed a system of domestic review and including a system of appeal, to ensure legal recourse and remedies in the event that the rules or procedures required by article 9 (1) of the Convention are not followed" añadiendo, poco después, que la Ley Modelo también "has been designed to be consistent, so far as practicable, with the approach to challenge procedures under the WTO GPA".

${ }^{27}$ Veja-se o parágrafo 26, p. 249, do Guia de Aplicação. Apesar do caráter neutral que os redatores da Lei Modelo quiseram outorgar ao termo ("the term "overturn" in those provisions has been chosen as a neutral one, as the Model Law is not designed to imply any particular legal consequences"), seu significado é que o órgão de revisão possa não apenas revogar ou anular mas tambén modificar o conteúdo da decisão adotada pela entidade adjudicadora. É por isso que, quando tal potestade não possa the ser reconhecida, "an alternative formulation would be to permit the independent body to annul the decision of the procuring entity, so that the procuring entity is then required to take another decision in the light of the decision of the independent body".

${ }^{28}$ Veja-se parágrafo 24, p. 248.

${ }^{29}$ Ibidem parágrafo 27, p. 249. Veja-se tambén NICHOLAS. op. cit., p. 227, onde, em referência aos trabalhos de revisão da Lei Modelo de 1994 sinala que "the aim of the provisions as described above is to facilitate early resolution of disputes through corrective action, and thus reduce the need for financial compensation".

${ }^{30}$ Vid. WILLIAMS-ELEGBE. Fighting corruption in public procurement. Oxford-Portland: Hart, 2012, p. 209 e ss. e também QUINOT, quem regista os câmbios experimentados nos regimens contratuais da UE e da UNCITRAL: "There has been recently a growing trend internationally to move away from the once strict notion of the irrevocability of concluded contracts or what some author called the notion of concluded public contracts as "sacred cows". In EU procurement law, the new Remedies Directive 2007/66, following judgements of the European Court of Justice, now requires national remedies regimes to provide for invalidity of concluded contracts under certains circumstances. Importantly, the new 2011 UNCITRAL Model Law also now provides, as an option, that independent review bodies may overturn concluded contracts" (cfr, QUINOT. A comparative perspective on supplier remedies in African public procurement systems. In: ARROWSMITH e QUINOT (Coords.). Public Procurement Regulation in Africa. Cambridge: Cambridge University Press, 2013, p. 327).
} 


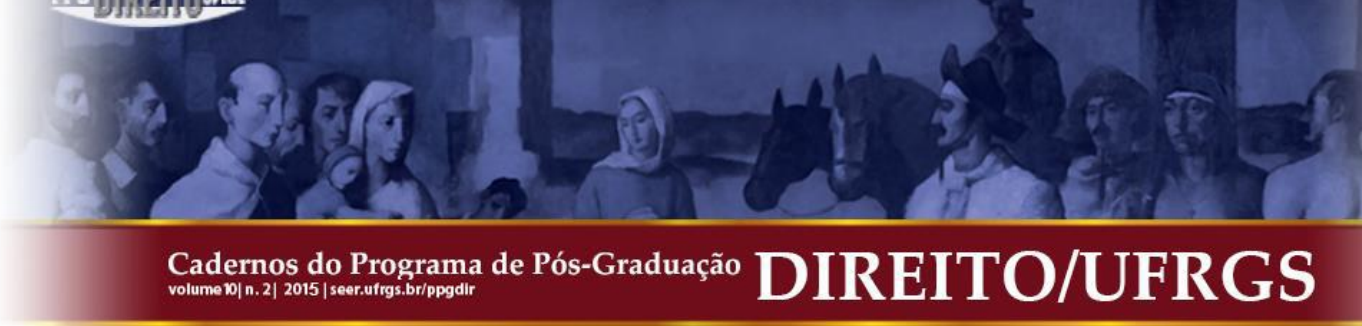

\subsection{Direito comunitário europeu}

Até a bem poucos anos, tanto o Direito comunitário quanto a maioria dos ordenamentos dos Estados membros assumiam a intangibilidade dos contratos já celebrados como um dogma praticamente indiscutível. Por graves ou numerosos que fossem os descumprimentos da normativa substantiva, os princípios de segurança jurídica e pacta sunt servanda fundamentavam, em certo modo, um bom senso jurídico não questionado por quase ninguém ${ }^{31}$.

De conformidade com a interpretação judicial da Diretiva 89/665/CEE, em sua versão original, os Estados membros só vinham obrigados a disponibilizar procedimentos de recurso que, além de reconhecer o direito a obter uma indemnização por danos e prejuízos, permitissem também obter " $a$ anulação da decisão do poder adjudicante de anterior à celebração do contrato de escolha do proponente com que se vai celebrar o contrato" 32 . Só isso. A eficácia dos procedimentos de recurso em matéria contratual impostos aos Estados membros pelo Direito comunitário não podiam atingir á validade dos contratos já adjudicados.

Tal era a situação até que o TJUE avançou mais outro passo. A STJUE de 10 de abril de $2003^{33}$, o mesmo que outras muitas antes de ela, declaro que a República Federal da Alemanha descumprira as obrigações decorrentes da Diretiva 92/50/CE, reguladora da adjudicação de contratos públicos de serviços, ao adjudicarem diretamente os munícipios de Bockhorn e Braunschweig dois contratos de saneamento de águas residuais e de recolha e

\footnotetext{
31 "The traditional and common perception in legal theory has clearly been that there is no duty based on EC law to terminate a public contract concluded in breach of the EC public procurement rules, regardless of the number of breaches or their character" (Cfr., TREUMER, S. Towards an obligation to terminate public contracts concluded in breach of EC Public Procurement rules - the end of the status of concluded public contracts as sacred cows. PPLR, 2007, 6, p. 371).

${ }^{32}$ Cfr., Acórdão do TJUE de 28 de outubro de 1999 (caso Alcaltel, C-81/98). No mesmo sentido o posterior de 24 de junho de 2004 (Comissão contra Aústria, C-212/02). O artigo 2.6 da Diretiva 89/665/CE estabelecia que "os efeitos do exercício dos poderes referidos no $n^{o} 1$ [medidas provisórias, anulação, indemnização] sobre o contrato celebrado na sequência da atribuição de um contrato de direito público serão determinados pelo direito nacional. Além disso, exceto se a decisão tiver de ser anulada antes da concessão de indemnizações, os Estados-membros podem prever que, após a celebração do contrato na sequência da atribuição de um contrato de direito público, os poderes da instância de recurso responsável se limitem à concessão de indemnizações a qualquer pessoa que tenha sido lesada por uma violação”.

${ }^{33}$ As. C-20/01 e 28/01, Comissão c. Alemanha. O Acórdao decide dois recursos formulados pela Comissão Europeia no quadro de dois procedimentos por descumprimento do Direito comunitário relativamente à adjudicação direta de dois contratos de serviços, um para o saneamento de águas residuais no município de Bockhorn e outro para a recolha e tratamento de lixo no de Braunschweig. Veja-se WILLIAMS. Remedying a breach of Community Law: the judgment in joined cases C-20/01 and C-28/01, Commission v. Germany. PPLR 2003, 5, p. 109 e ss.
} 


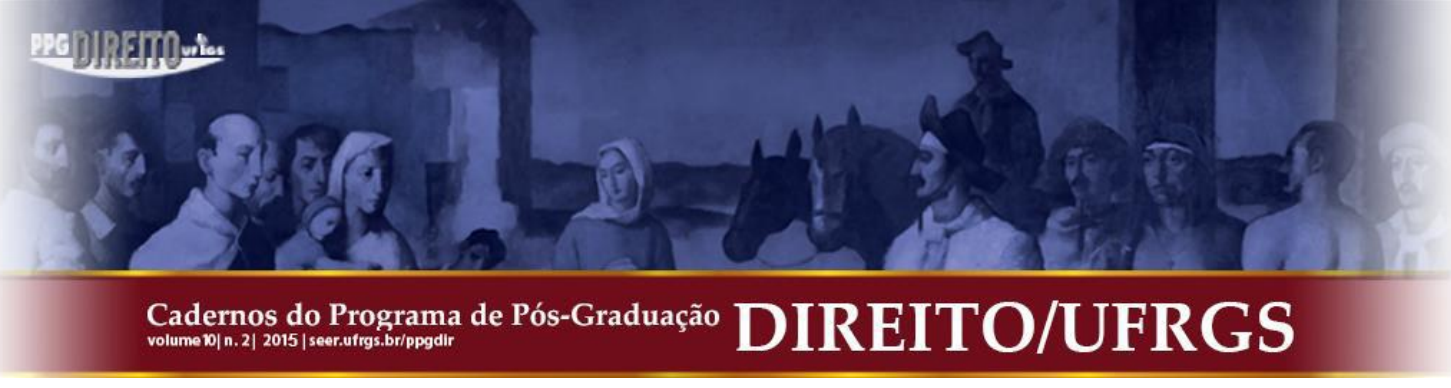

tratamento de lixo. Por enquanto, nada novo. A viragem, porém, reside en que ao rejeitar os argumentos alemães - a proteção dos direitos adquiridos e o princípio pacta sunt servanda, tirados da remissão que a Diretiva 89/665/CE, "recursos" faz ao Direito interno de cada Estado ao lhes permitir não anular os contratos adjudicados em violação do Direito comunitário da contratação pública se limitando a indemnizar às partes prejudicadas - o Tribunal realiza uma interpretação finalista da Diretiva 92/50/CE concluindo que se ela tem por objeto eliminar obstáculos à livre prestação de serviços, estes obstáculos persistirão entanto durar a execução dos contratos concluídos em infração da Diretiva ${ }^{34}$, sem que esta conclusão seja posta em causa "pela possibilidade oferecida aos Estados-Membros de, em conformidade com o artigo $2 .^{\circ}, n .{ }^{\circ} 6$, da Diretiva 89/665, limitar os poderes da instância de recurso responsável, após a celebração do contrato que se segue à adjudicação de um concurso, à concessão de indemnizações a qualquer pessoa que tenha sido lesada por uma violação do direito comunitário em matéria de concursos públicos" pois, "com efeito, apesar de, efetivamente, a referida disposição autorizar os Estados-Membros a manterem os efeitos de contratos celebrados em violação das diretivas em matéria de adjudicação de contratos públicos, protegendo, desse modo, a confiança legítima dos co-contratantes, a mesma não pode, sem diminuir o alcance das disposições do Tratado que estabelecem o mercado interno, ter como consequência que o comportamento da entidade adjudicante relativamente a terceiros deva ser considerado conforme ao direito comunitário após a conclusão desses contratos" 35 .

O descumprimento desta primeira decisão provocou que em dezembro de 2004 a Comissão acudisse novamente ao TJUE por meio da via aberta pelo artigo 228.2 Tratado da União Europeia (atual art. 260 do Tratado de Funcionamento da União Europeia) ${ }^{36}$

\footnotetext{
34 "Por conseguinte, cabe considerar que o prejuízo causado à livre prestação de serviços pela violação das disposições da Directiva 92/50 subsiste durante todo o período de execução dos contratos concluídos em sua violação" (parágrafo 36).

${ }^{35} \mathrm{O}$ sublinhado é meu. O Acórdão acolhe assim o argumento da Comissão segundo o qual, atendida a sua longa duração - 30 anos - "os contratos celebrados em violação do direito comunitário continuarão a produzir os seus efeitos durante décadas. Assim, o Governo alemão não pôs termo ao incumprimento. A impossibilidade de anular os contratos em causa não tem qualquer influência quanto à admissibilidade das ações, uma vez que é aos Estados-Membros que cabe escolher o modo adequado de reparação de um incumprimento" (parágrafo 28).

${ }^{36}$ De conformidade com a alínea 2 de este preceito "Se a Comissão considerar que o Estado-Membro em causa não tomou as medidas necessárias à execução do acórdão do Tribunal, pode submeter o caso a esse Tribunal, após ter dado a esse Estado a possibilidade de apresentar as suas observações. A Comissão indica o montante da quantia fixa ou da sanção pecuniária compulsória, a pagar pelo Estado-Membro, que considerar adequado às circunstâncias. Se o Tribunal declarar verificado que o Estado-Membro em causa não deu cumprimento ao seu acórdão, pode condená-lo ao pagamento de uma quantia fixa ou progressiva correspondente a uma sanção pecuniária. Este procedimento não prejudica o disposto no artigo 259".
} 


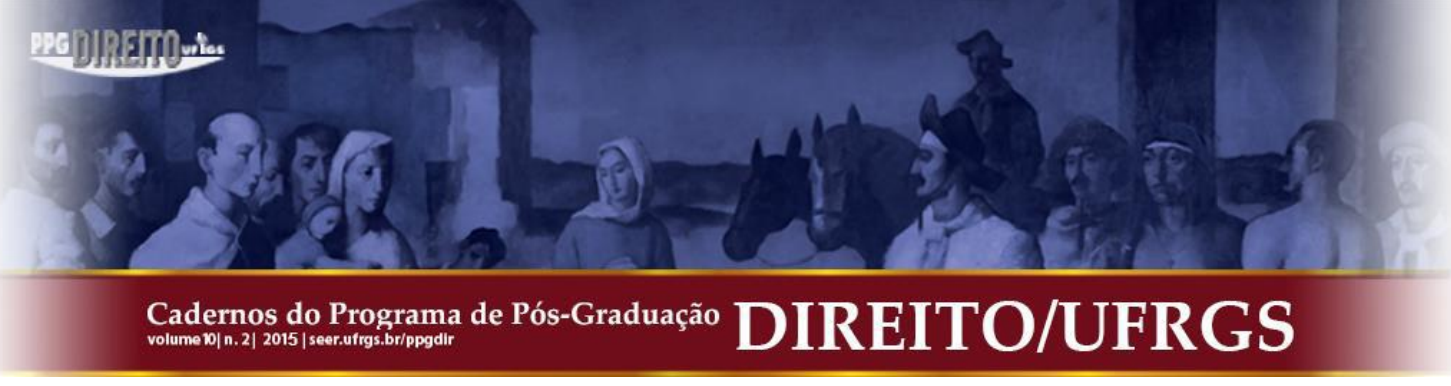

demandando a imposição de duas multas compulsórias por valor de $126.720 €$ diários no caso do contrato de saneamento de águas residuais e de $31.680 €$ diários no caso do contrato de recolha e tratamento de lixo. Como a quantia das multas fazia prever, os dois contratos foram finalmente rescindidos pelos municípios responsáveis. Todavia, como um de eles, em concreto o adjudicado pela comuna de Braunschweig, só foi rescindido em 4 de julho de 2005, isto é, mais de um mês após a finalização do prazo outorgado no Ditame da Comissão, ela não desistiu do recurso. Foi assim que o processo prosseguiu, culminando com o relevante Acórdão de 18 de julho de 2007.

Alemanha - com o apoio de outros países como França, Holanda e Finlândia manteve que a declaração de um descumprimento do Direito comunitário, além das indemnizações que eventualmente possam vir a ser satisfeitas, não pode supor em caso nenhum a anulação de um contrato já adjudicado, pois tal possibilidade não resultava imposta pela Diretiva 89/665/CE. Do seu ponto de vista, tal obrigação, caso de existir resultaria contrária aos "princípios da segurança jurídica e da proteção da confiança legítima, o princípio pacta sunt servanda, o direito fundamental de propriedade, o artigo $295 .{ }^{\circ} \mathrm{CE}$, bem como a jurisprudência do Tribunal de Justiça em matéria de limitação dos efeitos de um acórdão no tempo" ${ }^{, 37}$.

A Comissão, porém, manteve que a obrigação de cumprir os acórdãos declarativos do TJUE é uma norma de Direito originário que prima sobre o disposto na Diretiva s89/665/CE, com independência de que esta persiga uma finalidade bem mais específica que o recurso por descumprimento regulado no artigo $228 \mathrm{TUE}^{38}$, preceito este cujo alcance no âmbito do Direito da Contratação Pública a Corte já esclarecera com anterioridade ${ }^{39}$. Apoiada pelo

\footnotetext{
${ }^{37}$ Opinião compartida por NIESTEDT (Penalities despite compliance? A note on case C-503/04, Commission v Germany. PPLR 2005, 6) para quem, em 2005, “Community law does not oblige Member States to terminate contracts concluded in breach of the EU Procurement Directives in order to remove the consequences of the contravention. Article 2(6) of the Remedies Directive 89/665 states that the effects of the exercise of the powers provided for under the Remedies Directive on a contract concluded subsequent to its award are to be determined by national law and that national legal systems may permit that despite the unlawfulness of an award procedure, a concluded contract retains its validity". Para ela, definitivamente, "The question of whether a contract may be annulled or set aside is a matter falling within the competence of the Member State concerned, since the legal basis and extent of any termination are governed by national law. The Member States are free to limit the remedies that may be granted post conclusion of the contract to an award damages". Direito comunitário originário à margem, a reforma da Diretiva "recursos" em 2007 alterou radicalmente a situação.

${ }^{38}$ Em síntese, se a Diretiva trata de assegurar a existência de vias de reclamação eficazes caso de um particular se sentir agraviado pela atuação de um poder adjudicador contrária ao disposto no Direito comunitário, o recurso por descumprimento tem uma natureza objetiva: por meio de ele resolve-se uma controvérsia entre um Estado membro e as instituições comunitárias, decorrente de uma eventual infração do Direito comunitário.

${ }^{39}$ O Acórdão de 18 de novembro de 2004 (C-126/03) declara que "nos termos do artigo 226. ${ }^{\circ}$ CE, o Tribunal de Justiça seja unicamente obrigado a declarar que foi violada uma disposição do direito comunitário, resulta do
} 


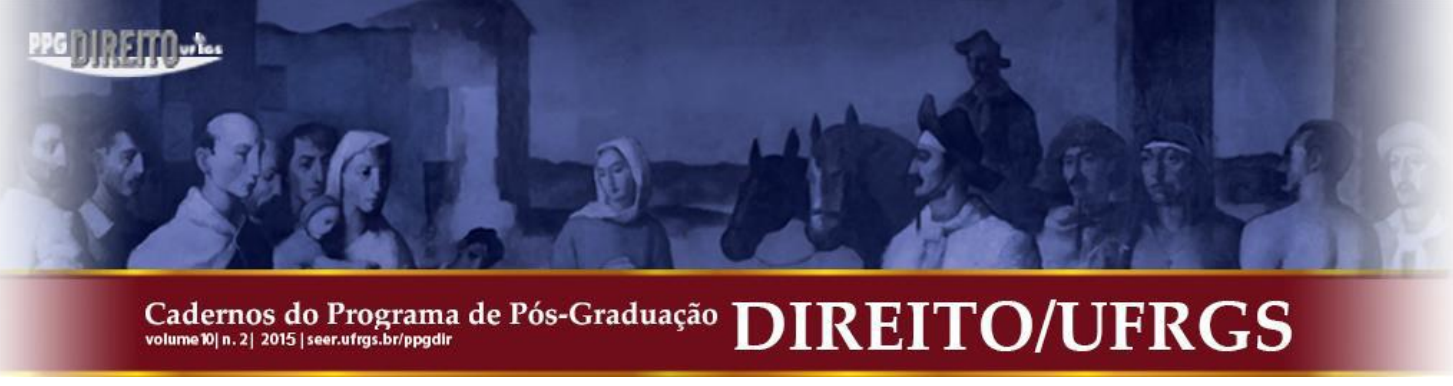

concluir que o referido dever surge sempre que o TJUE declarar qualquer descumprimento estatal ao abrigo do artigo 226 TCE (atual art. 258 TFUE). A seu ver, só de concorrerem determinadas circunstâncias, indissociáveis da análise individualizada do caso concreto, poderia afirmar-se a exigibilidade de esse dever. Circunstâncias tais como a gravidade da infração, o seu impacto sobre o mercado interior, o grau de execução do contrato e a necessidade de ponderar o interesse público e também, no seu caso, o dos terceiros que fizessem parte do contrato ${ }^{42}$.

Seja como for, a determinação do alcance desta obrigação de anular os contratos celebrados em infração do disposto nas Diretivas não deveria prescindir, como elemento hermenêutico fundamental, das Conclusões da Advogada Geral em este assunto C-503/04 que, no substancial, não se esqueça, foram aceites pelo tribunal em seu acórdão. Sustentando a existência de um dever geral de anular os contratos ilegalmente concluídos, a Advogada Geral invoca o princípio de efeito útil que, aplicado às Diretivas reguladoras da contratação pública, conduz à conclusão de que a afetação às liberdades de circulação de mercadorias e prestação de serviços "não se esgota, por isso, logo com a celebração do contrato, mas dura enquanto o contrato for integralmente cumprido ou até que tenha cessado por outro modo. Para que esta jurisprudência não seja esvaziada de sentido, o incumprimento verificado numa ação de incumprimento deve, por conseguinte, ser eliminado com a cessação do contrato"43. Alude também ao efeito dissuasivo que, de um ponto de vista preventivo, provocaria a afirmação desse dever para garantir, enfim, a aplicação efetiva do Direito comunitário ${ }^{44}$.

Em suma, pode-se concluir que a jurisprudência do TJUE obriga a anular ou cessar os contratos concluídos em violação grave do Direito derivado, isto é, das Diretivas reguladoras da contratação pública na UE. Obrigação fundada no Direito originário - neste caso, na liberdade de prestação de serviços - e nos seus princípios reitores - o efeito útil.

Sem dúvida, o legislador comunitário teve bem presente esta jurisprudência quando incluiu finalmente no artigo 2-E da Diretiva 2007/66/CE (que altera parcialmente a Diretiva 665/89, sobre processos de recurso em matéria de adjudicação de contratos públicos) a obrigação de declarar a ineficácia dos contratos já concluídos no caso de não publicação de

\footnotetext{
${ }^{42}$ Cfr., TREUMER, S. Towards an obligation to terminate public contracts concluded in breach of EC Public Procurement rules - the end of the status of concluded public contracts as sacred cows. PPLR, 2007, 6, p. 377 e ss. e também TREUMER, S. Enforcement of the EU Public Procurement Rules: The State of Law and Current Issues. en Enforcement of the EU Public Procurement Rules, DJØF Publishing, Copenhagen, 2011, p. 25 e ss.

${ }^{43}$ Cfr., parágrafo 76.

${ }^{44}$ Cfr., parágrafo 77.
} 


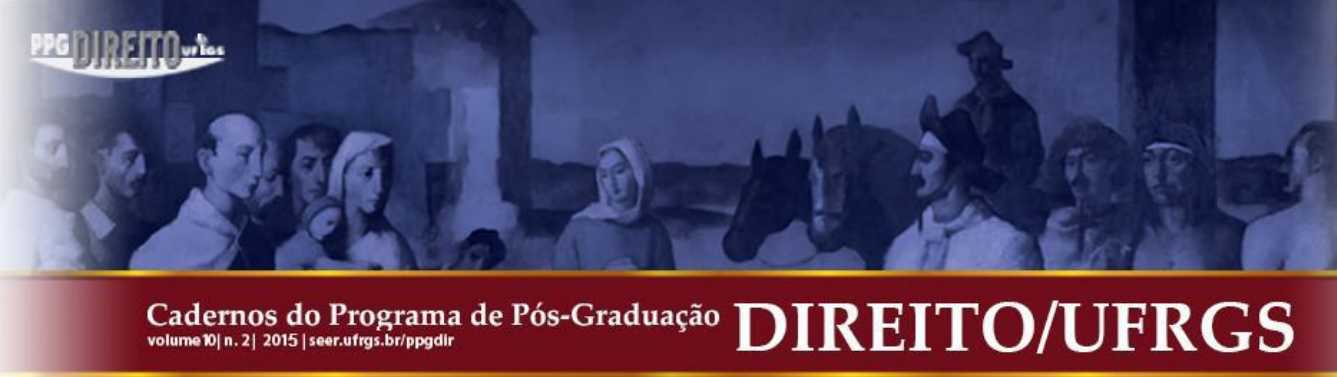

para a interposição do recurso contencioso-administrativo: apenas dois meses. À margem, claro é, da revisão de ofício que, como o seu próprio nome indica, depende de um impulso político e administrativo nem sempre existente. Mas, contudo, a possibilidade de os atos e contratos poderem ser anulados diretamente pela jurisdição penal não está isenta de problemas e dúvidas.

\subsection{A anulação de atos e contratos administrativos pela jurisdição criminal como questão prejudicial administrativa não devolutiva}

O acórdão da Sala Segunda do Tribunal Supremo 97/1994, de 18 de janeiro (caso "Burgos"), condenando ao prefeito, vereadores e empregados público do Concelho de Burgos bem como a um construtor pelos delitos de prevaricação, falsidade documental, revelação de secretos, denegação de auxílio à autoridade e desacato, anula também diversos acordos municipais de aprovação de instrumentos de planeamento urbanístico, concessão de licenças e até das escrituras públicas em que se inscreveram a nova situação urbanística das propriedades. Reconhecendo a complexidade da questão, o tribunal acaba por afirmar a competência anulatória da jurisdição criminal, considerando que, em essência, trata-se de um juízo de natureza administrativa realizado por um juiz do criminal ao abrigo do art. 3 LACrim (é dizer, de uma questão prejudicial não devolutiva) do qual decorre, de acordo com esse mesmo preceito, que tal decisão, adotada a "los únicos efectos de la represión" poderia ser revisada pela jurisdição contencioso-administrativa por carecer de força de coisa julgada.

Certamente, o fato de a norma administrativa aplicada vir a ser o art. 47.1.b) LPA antecessor do atual 62.1.d) LPAC - complica o assunto, dada a remissão que este preceito faz ao Direito Criminal e, em concreto, à existência de uma acórdão condenatória ditada por essa jurisdição que declare, nos seus fatos provados que o ato ou contrato administrativo de que se tratar foi meio ou consequência de um delito. É por isso que, rejeitando o motivo impugnatório aduzido pelo Concelho de Burgos no sentido de negar a competência da jurisdição criminal para anular atuações administrativas, a acórdão conclui dizendo que, mesmo no caso hipotético em que tal argumento fosse estimado, "el resultado prácticamente no conduciría a nada, (porque) la jurisdicción contencioso- administrativa estaría vinculada por lo declarado por el Juez penal". 


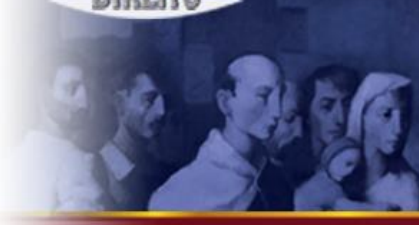

\subsection{A anulação de atos e contratos administrativos como manifestação da competência civil adesiva do juiz penal}

De acordo com o estabelecido pelo art. 742.2 da Lei de Ajuizamento Criminal (de aqui à frente, LACrim), enquanto o exercício das ações civis não fosse expressamente reservado para um processo posterior, o juiz do criminal é competente para resolver "todas las cuestiones sobre responsabilidad civil que hayan sido objeto de juicio". Pela sua parte, o art. $110 \mathrm{CP}$ especifica que a responsabilidade civil decorrente de um ilícito criminal compreende a restituição, a reparação do dano e a indemnização de prejuízos materiais e morais. Face o que em um início pudesse deduzir-se da letra destes preceitos, uma jurisprudência consolidada sustenta que tal "competencia civil adhesiva" do juiz criminal não se circunscreve apenas ao âmbito estritamente indenizatório porquanto pode incluir também pronunciamentos acerca da validade dos negócios jurídicos relacionados com o fato delitivo, em tanto que meios para a sua comissão ou consequência dele ${ }^{53}$. Além do mais, a diferença de outros pronunciamentos civis realizados a título prejudicial ao abrigo do estabelecido pelo art. 3 LACrim, os que a acórdão criminal contiver em matéria de responsabilidade ditam-se no exercício de uma competência própria e beneficiam-se da força de coisa julgada produzindo, tal e como a jurisprudência tem declarado, a consunção das correspondentes ações que já não poderão ser exercitadas perante a jurisdição civil ${ }^{54}$. Embora reconhecendo as suas vantagens, não devem obviar-se os inconvenientes que envolvem esta conversão da competência civil adesiva do juiz criminal, inicialmente limitada ao âmbito ressarcitório, numa potestade genérica de restauração da ordem jurídica alterada pelo delito que, como competência de atribuição, compreenderia quantos pronunciamentos estivessem funcionalmente orientados ao logro de tal finalidade. $\mathrm{O}$ risco faz-se ainda mais evidente quando o avanço tem lugar sobre o

\footnotetext{
${ }^{53}$ Cfr., ARNÁIZ SERRANO, A. La acción civil en el proceso penal: elementos objetivos. Tesis Doctoral, Univeridad Carlos III, Madrid, 2004, p. 315

${ }^{54}$ Em referência à responsabilidade civil, o Acórdão da Sala Segunda do Tribunal Supremo de 18 de Outubro de 1988 declara que "cuantas acciones tengan cabida en el proceso penal se han de entender ejercitadas en él y por lo mismo juzgadas en el fallo condenatorio, con efectos siempre consuntivos de todas ellas". Seja como for, a doutrina civilista matiza o alcance da consunção ao estimar que ela só se produze quando a acórdão contenha uma declaração expressa sobre a invalidade ou a ineficácia do negócio. Em todos os demais supostos - quando não se pronunciar sobre o particular o se o fizesse exclusivamente na fundamentação - YZQUIERDO TOLSADA considera (cfr., op. cit., p. 1194) que as ações subsistem e poderiam se exercitar perante a jurisdição civil.
} 


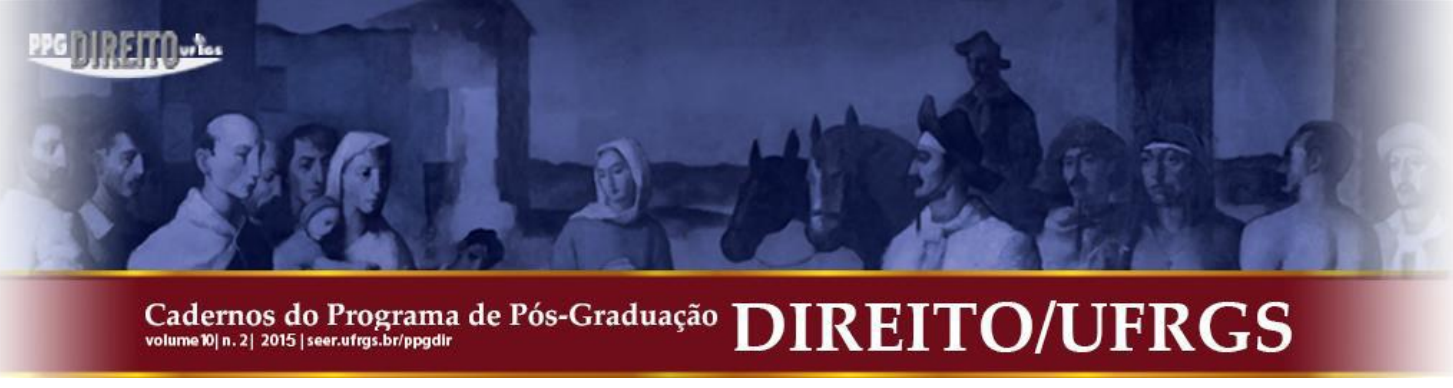

Amostra do primeiro dos problemas indicados é a Acórdão 73/2013, de 26 de julho, da Audiência Provincial das Ilhas Baleares, ditada no conhecido como caso "Scala". A acórdão condena a um ex conseller ${ }^{57}$, a um ex-diretor geral do governo balear, à gerente do Consórcio de Desenvolvimento Económico de Baleares (CDEIB) bem como a outras doze pessoas pelos delitos de associação ilícita, prevaricação, malversação, fraude à Administração Pública, suborno e falsificação de documentos públicos y mercantis. O tribunal considera provada a existência de uma trama para desviar recursos públicos desde o CDEIB por meio de contratos públicos adjudicados, sem procedimento nenhum, a empresas controladas pelos cargos públicos condenados por meio de testas-de-ferro, a cobrança de comissões aos fornecedores de bens e serviços que, em muitas ocasiões, nem sequer chegaram a se prestar. Quando a acórdão, no âmbito da responsabilidade civil, declara a nulidade de alguns dos contratos públicos celebrados pela rede delitiva invoca, em exclusiva, o art. $1275 \mathrm{CC}$.

No que diz respeito à legitimação, o enquadramento da nulidade dentro da responsabilidade civil supõe que ela só possa ser declarada se algum dos prejudicados ou o Ministério Público exercita esta ação de acordo com o disposto nas normas civis. Por esta razão são tão escassas as declarações de nulidade de atos e contratos realizadas pela jurisdição criminal: salvo que houver câmbios na maioria governante, a principal prejudicada por estes delitos - a Administração - é muito relutante a demandar anulação nenhuma ${ }^{58}$. Pela sua parte, a falta de um critério assente, o Ministério Público atua de forma errática, reclamando em uns casos nulidades que não demanda em supostos análogos ${ }^{59}$. As outras partes acusadoras, de existirem, não estariam em princípio legitimadas para exercitar a ação de responsabilidade civil.

\footnotetext{
${ }^{57}$ Membro do governo autonómico.

${ }^{58}$ Vid. Acórdão da Sala Segunda do Tribunal Supremo 537/2002, de 5 de abril. Condena-se por prevaricação em concurso com tráfico de influências a diversos integrantes do governo municipal de Marbelha pela celebração irregular de contratos de patrocínio de clubes e entidades desportivas a meio do concelho marbelhi ou da sociedade municipal "Eventos 2000". Contudo, ao não se ter personado na causa o município de Marbelha, o tribunal não estima a demanda de nulidade dos contratos celebrados: "la Sala no hace pronunciamientos sobre las responsabilidades civiles ni sobre las nulidades contractuales solicitadas, reservándose ello en su caso a la vía jurisdiccional correspondiente".

${ }^{59}$ No caso "Turismo", análogo ao "Scala" já analisado, a Acórdão de 13 de Outubro de 2005 da Audiência Provincial de Barcelona não contém pronunciamento nenhum relativo à nulidade dos contratos por não ter sido aquela solicitada nem pela Generalitat e também não pelo Ministério Público.

À idêntica conclusão chega-se comparando a Acórdão do caso “Asesores”, já referida, com a 273/2014, de 16 de Julho, ditada pela Audiência Provincial de Ourense no assunto "Baltar", que condena ao ex presidente da Deputação Provincial de Ourense a nove anos de inabilitação especial para cargo público em quanto que responsável de um delito continuado de prevaricação pela contratação de 104 pessoas com infração dos princípios básicos reitores da contratação e do acesso ao emprego emprego público embora sem anular nenhum destes contratos rejeitando, além do mais, a reclamação indenizatória formulada pela acusação particular.
} 


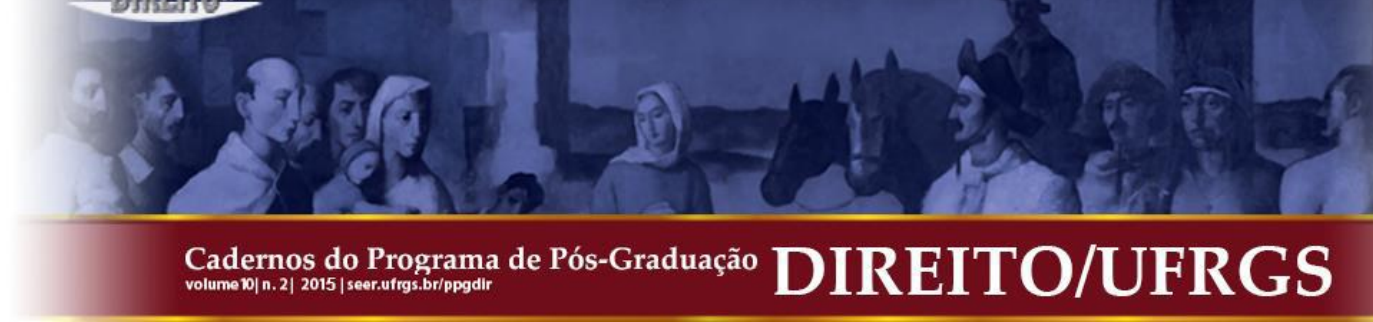

\subsection{Um caso excecional: a jurisdição criminal declara-se incompetente para anular atuações administrativas}

Apenas em um caso, o decidido pelo Acórdão 16/2012, de 30 de novembro, do Tribunal Superior de Justiça da Comunidade Valenciana, um órgão da jurisdição criminal declarou-se expressamente incompetente para anular atuações administrativas, considerando que, ao fazê-lo, estaria a invadir um âmbito que o art. 9.4 LOPJ reserva à jurisdição contencioso-administrativa ${ }^{60}$. Com efeito, após situar as pretensões anulatórias formuladas pelo Ministério Público no âmbito da responsabilidade civil e interpretar restritivamente o alcance desta "competência civil adesiva" suporia uma invasão das competências privativas da ordem contencioso-administrativo envolvendo a nulidade do atuado.

A particularidade do caso em apreço reside em que ao se declarar incompetente o tribunal criminal para anular o contrato, este deveio inatacável ao ganhar firmeza o ato de adjudicação e não ter intenção alguma o concelho de Torrevieja, ao menos num primeiro momento, de revisar de ofício o contrato. Ficaria apenas a via do recurso administrativo de revisão pela concorrência do quarto motivo de entre os enumerados no art. 118.1 da Lei de Regime Jurídico das Administrações Públicas e do Procedimento Administrativo Comum (em diante, LPAC) muito limitado, em qualquer caso, como consequência da restritiva interpretação que dele realizam a doutrina jurisprudencial e consultiva.

O acórdão rejeita, uma por uma, todos os argumentos em que a jurisprudência maioritária funda a competência dos juízes do criminal para anularem atos e contratos administrativos. Nega, em primeiro lugar, que a "competência civil adesiva” possa vir a dar

\footnotetext{
${ }^{60} \mathrm{O}$ acórdão condenou ao ex prefeito popular de Torrevieja por um delito continuado de prevaricação e falsidade em documento oficial a três anos de prisão, sete meses de multa e sete anos de inabilitação especial para cargo eletivo local por manipular o procedimento de contratação do serviço de recolha de lixo e limpeza viária, logrando que fosse adjudicado a uma UTE encabeçada pela empresa NECSO e encargando diretamente, entre outras atuações, um parecer a um escritório de advogados vinculado com a empresa a fim de esquivar os pareceres internos que aconselhavam deixar o concurso deserto.

61 "Según dispone el artículo 110 del Código Penal y el 100 de la Ley de Enjuiciamiento Criminal, acciones civiles ejercitables en el proceso penal son tan solo la restitución de la cosa, la reparación del daño y la indemnización de perjuicios materiales y morales causados por el hecho ilícito".
} 


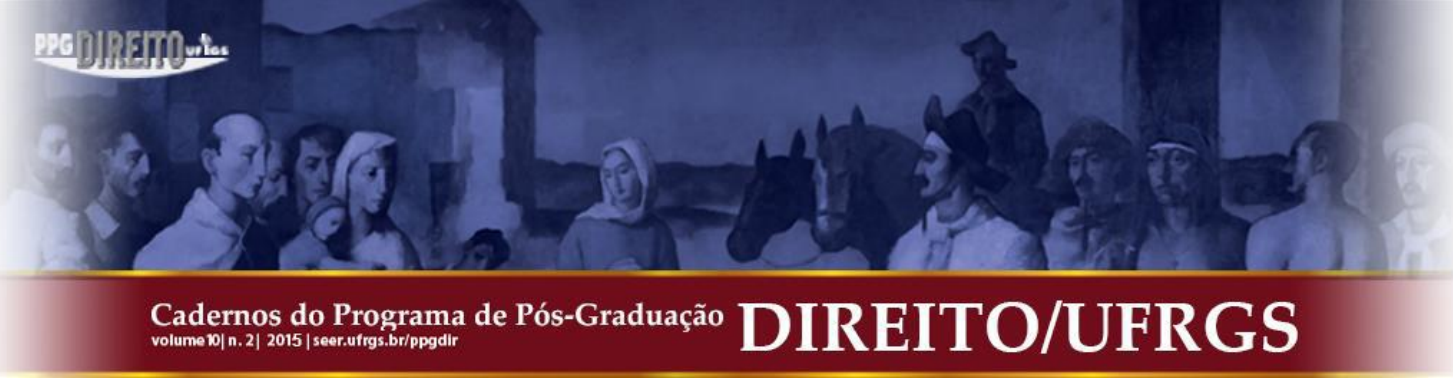

Em 16 de Janeiro de $2014^{64}$, o Consell Juridic Consultiu valenciano informou favoravelmente, a pedido do concelho de Torrevieja, a rescisão do contrato de gestão do serviço público de recolha de resíduos sólidos, transporte à lixeira, limpeza viária e manutenção do litoral do território municipal a causa das "reiteradas deficiencias en la prestación por la concesionaria de los servicios contratados" que não poupam nenhuma das prestações objeto do contrato. De modo que dez anos após a adjudicação do contrato e depois inúmeros incumprimentos, o concelho procede finalmente resolver ele. Logo surge a pregunta de se não teria sido melhor - em termos de justiça e de eficiência, em definitiva, de boa administração - que o contrato se anulasse pelo acórdão que comentamos.

\section{CONCLUSÃO. A ANULAÇÃO dE ATOS E CONTRATOS ADMINISTRATIVOS COMO CONFISCO DOS PRODUTOS DO DELITO}

Todos os instrumentos internacionais de luta contra a corrupção partem do princípio de que a corrupção não pode compensar e que, consequentemente, os Estados signatários devem confiscar o produto da corrupção ou aplicarem sanções pecuniárias de efeito equivalente ${ }^{65}$. O confisco do produto dos delitos de corrupção engloba também a "caducidade dos direitos" $" 66$ noção dentro da qual, sem esforço, cabe considerar incluída a nulidade de atos e contratos públicos.

Idêntica preocupação por que o delito não resultar proveitoso ${ }^{67}$ inspira as iniciativas que, com o art. 83.1 Tratado de Funcionamento da União Europeia como pano de fundo ${ }^{68}$, impulsionam as instituições comunitárias privilegiando o confisco na sua dupla dimensão

\footnotetext{
${ }^{64}$ Parecer 2014/0020. Pode consultar-se ewww.gva.es/cjccv/.

${ }^{65}$ Cfr., art. 3.3 da Convenção OCDE de luta contra a corrupção de agentes públicos estrangeiros nas transações comerciais internacionais; art. 19.3 da Convenção Criminal sobre Corrupção do Conselho de Europa; art. 31 da Convenção das Nações Unidas contra a Corrupção.

${ }^{66}$ Cfr., "Comentarios al Convenção de la OCDE de Lucha contra la Corrupción de Agentes Públicos Extranjeros en las Transacciones Comerciales Internacionales", en Convenção de la OCDE de Lucha contra la Corrupción de Agentes Públicos Extranjeros en las Transacciones Comerciales Internacionales. Información para las empresas españolas con actividades en el extranjero, pág. 35 (documento informativo publicado pelo governo espanhol acessível

em http://www.mjusticia.gob.es/cs/Satellite/1292427004774?blobheader=application\%2Fpdf\&blobheadername1=C ontent-Disposition\&blobheadervalue 1=attachment\%3B+filename\%3DFolleto_sobre_el_Convenção.PDF).

${ }^{67}$ Cfr., Comunicação da Comissão ao Parlamento Europeu e ao Conselho, Produto da criminalidade organizada. Garantir que “o crime não compensa”, COM(2008) 766 final.

${ }^{68}$ Preceito que inclui a corrupção como um dos crimes de "especial gravidade" e "repercussão transfronteiriça" nos que as instituições comunitárias poderão estabelecer, por meio de Diretivas, critérios comuns para a sua perseguição no conjunto da UE. De acordo com o art. 10 do Protocolo 36 TFUE, esta previsão vigora desde 1 de Dezembro de 2014.
} 


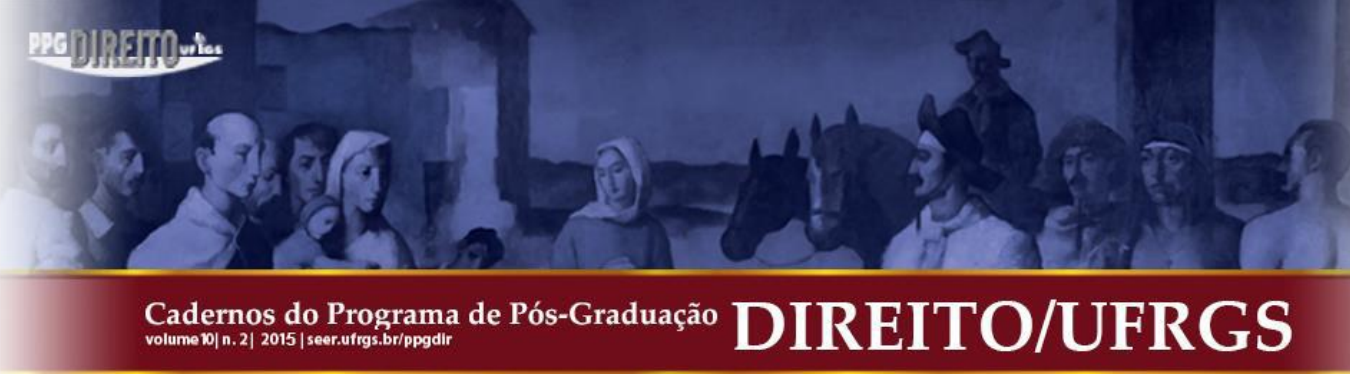

Para o Brasil, estas conclusões também parecem válidas toda vez que a Convenção Interamericana contra a Corrupção (1996) regula o confisco no seu artigo XV, "Medidas sobre bens". Concretamente, na alínea 2 se estabelece que "1. Em conformidade com as legislações nacionais aplicáveis e os tratados pertinentes ou outros acordos que estejam em vigor entre eles, os Estados Partes prestarão mutuamente a mais ampla assistência possível para identificar, localizar, bloquear, apreender e confiscar bens obtidos ou provenientes da prática dos delitos tipificados de acordo com esta Convenção, ou os bens usados para essa prática, ou o respectivo produto" acrescentando o número seguinte que "2. O Estado Parte que executar suas próprias sentenças de confisco, ou as sentenças de outro Estado Parte, a respeito dos bens ou produtos mencionados no parágrafo anterior deste artigo, disporá desses bens ou produtos segundo sua própria legislação. Na medida em que o permitirem suas leis e nas condições que considere adequadas, esse Estado Parte poderá transferir esses bens ou produtos, total ou parcialmente, para outro Estado Parte que tenha prestado assistência na investigação ou nas diligências judiciais conexas". Note-se, aliás, que de conformidade com o artigo I, por "bens" devem entender-se "os ativos de qualquer tipo, quer sejam móveis ou imóveis, tangíveis ou intangíveis, e os documentos e instrumentos legais que comprovem ou pretendam comprovar a propriedade ou outros direitos sobre estes ativos, ou que se refiram à propriedade ou outros direitos".

\section{REFERÊNCIAS}

ARNÁIZ SERRANO, A. La acción civil en el proceso penal: elementos objetivos. Tesis Doctoral, Univeridad Carlos III, Madrid, 2004.

ARROWSMITH, S. The character and role of national challenge procedures under the Government Procurement Agreement. PPLR, 2002, 4.

BAUZÁ MARTORELL, F. El acto administrativo: entre nulidad y delito (la anulación de actos administrativos por el juez penal). REDA $\mathrm{n}^{\mathrm{o}} 163,2014$.

GIMENO FELIU, J.M., (2010) La Ley de Contratos del Sector Público ¿una herramienta eficaz para garantizar la integridad?. Mecanismos de control de la corrupción en la contratación pública. REDA, nº 147. 


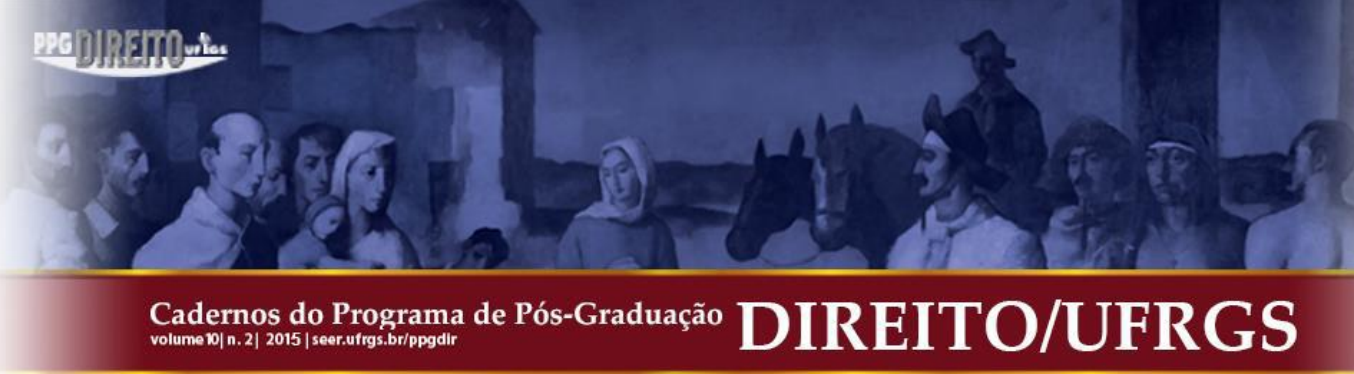

GIMENO SENDRA, V. Estudio preliminar. Cuestiones prejudiciales devolutivas y non bis in idem en el proceso penal. In: BALLBÉ MALLOL y PADRÓS REIG. La prejudicialidad administrativa en el proceso penal. Madrid: Civitas, 2004.

MEDINA ARNÁIZ, T. La regulación europea de la contratación pública no se agota en las Directivas: Nota sobre el nuevo Reglamento Financiero de la Unión. Disponível em http://www.obcp.es/index.php/mod.opiniones/mem.detalle/id.90/relcategoria.121/relmenu.3/c hk.39ec8e37560acccc5bdd63b3274ae53b.

Instrumentos jurídicos frente a la corrupção en la contratação pública: perspectiva europea y su incidencia en la legislação española. In: FERNÁNDEZ ACEVEDO, R. y VALCÁRCEL FERNÁNDEZ, P (Coords.) La contratación pública a debate: presente y futuro. Madrid Civitas-Thomson Reuters.

MORCILLO MORENO, J. Teoría y práctica de las cuestiones prejudiciales en el ámbito del Derecho Administrativo. Madrid: La Ley, 2007.

NICHOLAS. Remedies for breaches and UNCITRAL Model Law. Public Procurement Law. Damages as an Effective Remedy. Oxford: Hart, 2011.

NIESTEDT. Penalities despite compliance? A note on case C-503/04, Commission v Germany. PPLR 2005, 6.

OCDE. OECD Foreign Bribery Report. An analysis of the Crime of Bribery of Foreign Officials. Paris: OECD Publishing, 2014.

QUINOT. A comparative perspective on supplier remedies in African public procurement systems. In: ARROWSMITH e QUINOT (Coords.). Public Procurement Regulation in Africa. Cambridge: Cambridge University Press, 2013.

TREUMER, S. Towards an obligation to terminate public contracts concluded in breach of EC Public Procurement rules - the end of the status of concluded public contracts as sacred cows. PPLR, 2007, 6.

. Enforcement of the EU Public Procurement Rules: The State of Law and Current Issues. en Enforcement of the EU Public Procurement Rules, DJØF Publishing, Copenhagen, 2011. 


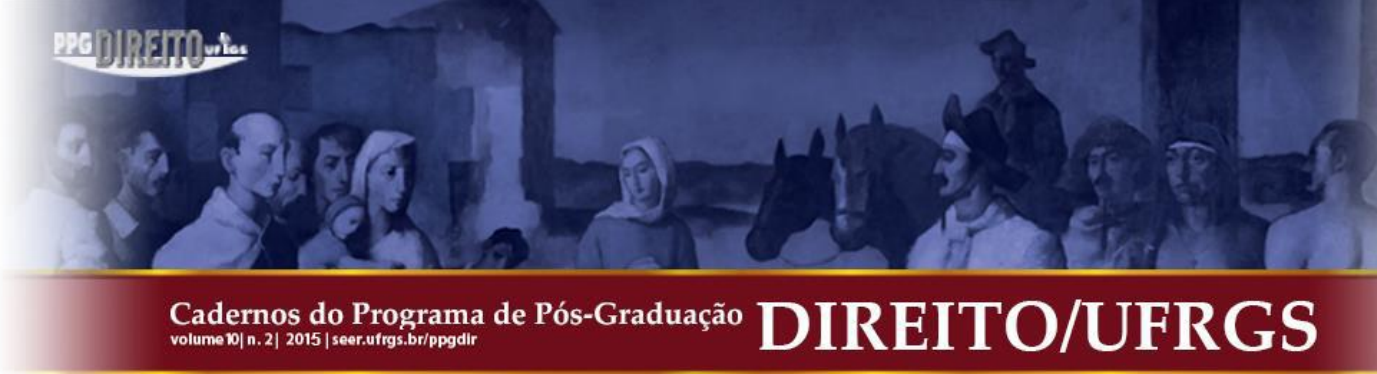

WILLIAMS. Remedying a breach of Community Law: the judgment in joined cases C-20/01 and C-28/01, Commission v. Germany. PPLR 2003, 5.

WILLIAMS-ELEGBE, S. Fighting corruption in public procurement. Oxford-Portland: Hart, 2012.

XINGLIN ZHANG. Constructing a system of challenge procedures to comply with the Agreement on Government Procedure. In: ARROWSMITH y ANDERSON (Eds.). The WTO Regime on Government Procurement: Challenge and Reform. Cambridge: Cambridge University Press, 2011.

YZQUIERDO TOLSADA, M. La responsabilidad civil en el proceso penal. In: BUSTO LAGO y REGLERO CAMPOS (Coords.). Tratado de Responsabilidad Civil. 5. ed. Madrid: Civitas, 2014.

Submissão: $13 / 10 / 2015$ Aceito para Publicação: 13/10/2015 


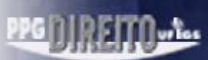

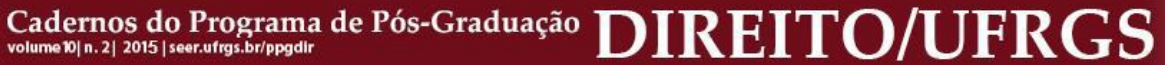

